\title{
National Treatment for All Non-resident EU Nationals: Looking Beyond the D Decision
}

\author{
Prof. Dr. Pasquale Pistone, Associate Professor of Tax Law at the University of Salerno, Italy
}

The Grand Chamber of the European Court of Justice said its final words on the (ir)relevance of the mostfavoured-nation clause in the light of the EC Treaty. Some sectors, however, are rejuvenating the debate on this ever-controversial issue, including those who try to reconcile the $\mathrm{D}$ case with previous tax cases (like the Wallentin case) and non-tax decisions (such as that involving the Gottardo case).

For the purpose of allowing a thorough debate before the European Court of Justice and to decide two other issues raised by the pending cases Bujara and Test Claimants in Class IV of the ACT Litigation Group, Intertax will publish various articles on tax issues of the MFN saga starting with this issue.

Meanwhile, may I take this opportunity to express the mixed feelings that the $D$ decision has caused as regards an opponent of the judicial application of the MFN, especially some arguments put forward by the European judges who seem to have left a cloud of uncertainty over the relations between tax treaties and European law.

The Saint-Gobain decision opened the era in which Member States had to comply with the primacy of European law even when tax treaties had been concluded with third countries. ${ }^{1}$ The problem arose from the non-entitlement of a permanent establishment to the benefits of German treaties (with non-EU Member States). The ECJ settled it by obliging Germany to give PEs an equivalent treatment on the basis of its domestic law. In the later Open skies decisions, the Court added that compliance with fundamental freedoms would be ensured even if this would compromise the rights enjoyed by non-EU Member States on the basis of a treaty. ${ }^{2}$

In the $D$ decision, after recalling the need to give PEs the same tax treatment applicable under the treaty (based on the Saint-Gobain decision), the ECJ stated that treaties only applied to persons who were residents in one or both Contracting States and therefore Belgian residents would be different from
non-Belgian residents in respect of ownership of Dutch immovable property. ${ }^{3}$

Regardless of the questionable logical connection between the two parts of the preceding sentence, treaties are indeed a consistent set of rules: a package deal whereby reciprocal concessions are to be framed within the overall balance achieved between the two Contracting States. ${ }^{4}$ When a non-discrimination provision grants national treatment to residents of the other Contracting State, it proves that both States acknowledge that non-residents are in fact resident taxpayers insofar as allowances are concerned. Otherwise, it would not be a non-discrimination provision, but rather a treaty clause granting tax advantages, and indeed removing discrimination is not an advantage in technical terms, but rather a goal set by the treaty to eliminate an existing obstacle arising from crossborder situations.

This leads me into saying that provided that personal and family situations are not taken into account in the other State, countries executing tax treaties like the one involving the Belgium-Netherlands DTC should in fact grant national treatment.

Even if the EC treaty does not in principle require treating two non-residents (non-nationals) of two different EU Member States under the same rights, it gives both a full entitlement to national treatment provided that certain conditions are met. Consequently, fundamental freedoms could be interpreted in a way as to require countries granting national treatment on the basis of their tax treaties to do the same in respect of other EU nationals on the basis of the EC Treaty.

This interpretation would strengthen the role of national treatment, which could become the key to addressing most MFN problems in the proper framework of legal relevance set by the EC Treaty.

The Court though did not follow this approach and rather kept interpreting the equal treatment of nonresidents within the traditional Schumacker threshold.

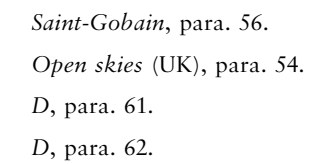


Arguably, it did so even in a case that could have been decided differently, whereas Mr. D's situation was to be taken into account at least once (because of the lack of a net wealth tax in his State of residence).

Had he only been in a situation like Mr. Wallentin's (without a taxable economic strength outside the host State), then his treatment would have been different not because of the Court's questionable statement on the difference between Mr. Wallentin's non-taxable income (owing to a non-taxable threshold) and $\mathrm{Mr}$. D's non-taxable wealth ${ }^{5}$ (owing to the absence of a tax thereon), but rather because it required compliance with the Court's criteria - a formal compliance with legal criteria, which sometimes may raise questionable legal technicalities.

Tax treaties and national sovereignties will not be strongly affected by the $D$ decision, if not to the extent that the MFN issue has now become even more unlikely to be accepted by the European Court of Justice. Especially because of the parallel case with the Saint-Gobain decision within the context of the $D$ decision, the impact of para. 61 of the latter decision on the exercise of taxing powers through treaties will thus be very limited.

However, shortly after the Saint-Gobain decision, the ECJ did apply the provisions of a social security convention to a person (Elide Gottardo) who was a national of neither Contracting State. Why did the Court view the treaty as applicable to her, whereas it refrained from following the same approach as regards Mr. D? Were the two different?

These questions were neither raised, nor otherwise addressed by the ECJ. However, it is presumed that some relevant differences indeed exist between the two cases, thus reconciling the positions respectively held by the Court.
First and most importantly, the area of European law directly involved in the Gottardo case was social security (the prime concern of common EU policy), whereas only one national law normally regulates the position of the worker and his/her pension rights.

Furthermore, Mrs. Gottardo was not invoking her pension rights as to entitle her to the so-called mostfavoured-nation treatment, but merely to enjoy the same rights to which Italian nationals are entitled under the social security convention with Switzerland. She had previously claimed that she was no longer entitled to the same benefits since she had married a French citizen.

In short, the $D$ decision may have said the final word, but certainly not the final arguments, on the issue of the judicial application of the MFN treatment under the EC Treaty. The debate among scholars, as well as the opinion to be delivered by AGs in the two pending cases and the decisions of the ECJ, certainly will.

Meanwhile, the Decision 578 of the Andean Community of Nations (effective as of January 1, 2005) proves that other options may be taken to introduce an obligation to grant the most-favourednation treatment. Such decision says 'no Member State shall apply to persons domiciled in other Member States a less favourable treatment than that applicable to persons domiciled on its own territory'. ${ }^{6}$

MFN clauses included in an increasing number of bilateral tax treaties (many more that I had initially found out) give further examples of how such treatment has taken on such importance in many parts of the world - an important matter for the Courts, but probably only insofar as the Contracting States have specifically decided to grant such treatment under each treaty.

\section{Notes}

D, para. 42

6 Loose translation of the author from the official text of Article 18 in Spanish: 'Ningún país miembro aplicará a las personas domiciliadas en los otros países miembros, un tratamiento menos favourable que el que aplica a las personas domiciliadas en su territorio'. 